\title{
Redistribution in an age of neoliberalism: Market economics, 'poverty knowledge', and the growth of working-age benefits in Britain, c. 1979-2010
}

\author{
Peter Sloman \\ University of Cambridge
}

\section{Introduction}

The 2008 financial crisis and the subsequent recession have pushed distributional questions to the top of the political agenda across the west for the first time in a generation. In Europe and the United States, anti-austerity groups such as Occupy have mobilized public concern about the power of the financial sector and the growing concentration of wealth in the hands of the ' $1 \%$ '. Within British politics, the period since 2010 has been characterized by a renewed focus on low pay and economic insecurity, pioneered by Ed Miliband and think-tanks such as the Resolution Foundation but increasingly taken up across the political spectrum. The National Living Wage for workers aged 25+, introduced by George Osborne in April 2016 and due to rise to 60 per cent of median earnings by the end of the decade, is designed to reduce reliance on in-work benefits and make Britain a 'higher wage, lower tax, lower welfare country' (Osborne, 2015). In the wake of the UK's vote to leave the European Union, Jeremy Corbyn and John McDonnell have sought to outbid the Conservatives by promising to extend the National Living Wage to 18-24 year olds and increase it to 'the level needed for a decent life' - expected to be more than $£ 10$ an hour by 2020 (McDonnell, 2016; Labour Party, 2017: 47).

This bipartisan commitment to raising the wage floor is striking because it represents a reversal of a half-century-long trend in British public policy: of moving away from direct 
intervention in the economy and relying instead on cash transfers to alleviate poverty. Jacob Hacker (2011: 35) has drawn an influential distinction between 'pre-distribution' policies, designed to influence the initial 'distribution of economic power and rewards' through the structure of labour and product markets, and the 'redistribution' of income between households through the tax and benefit systems. Since the 1970s, the UK's political economy has been reshaped both by the processes of privatization and deregulation associated with neoliberalism - rolling back the 'pre-distributive' interventions of post-war social democracy - and by the continued growth of welfare spending, from 4\% of GDP in the late 1940s and $8 \%$ in the mid-1970s to more than $12 \%$ in 2010 (Figure 1). The growth of the social security budget has partly been driven by demographic changes such as the rising number of pensioners, but it also reflects the growing use of benefits to supplement the incomes of working families. Indeed, transfer payments to working-age adults and children have trebled in real terms since Margaret Thatcher took office in 1979 (Figure 2). Although support for unemployed and disabled people has undergone important changes, the most striking quantitative shift has been the rise of in-work benefits. Tax credits and Housing Benefit are now the second- and third-largest elements of the social security budget after the state pension. 


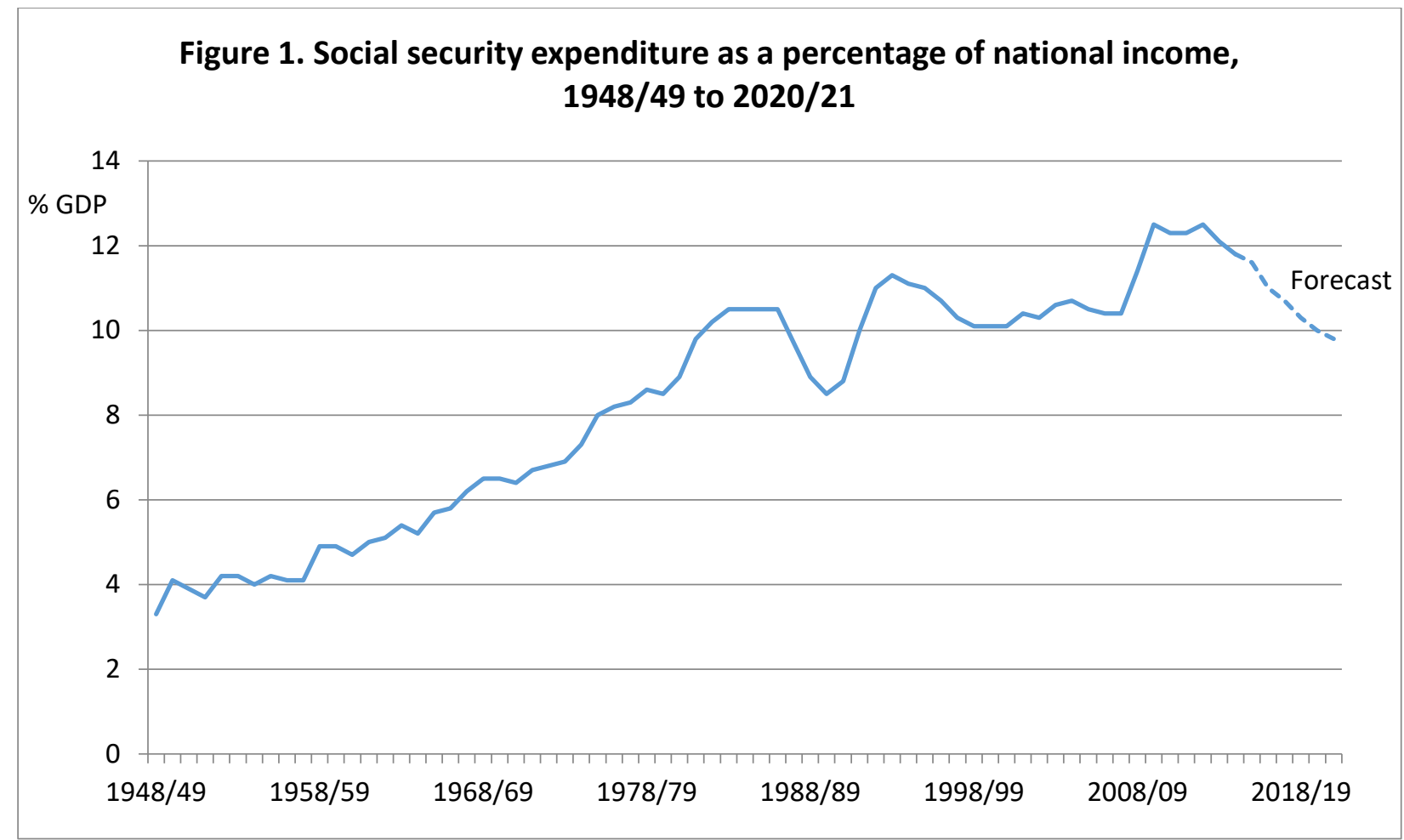

Source: Institute for Fiscal Studies, 'Social security spending', 29 September 2015:

www.ifs.org.uk/tools_and_resources/fiscal_facts/public_spending_survey/social_security

\section{Figure 2. Transfer payments to working-age adults and children in Great Britain: $1978 / 79$ to $2017 / 18$ (real terms, 2017/18 prices)}

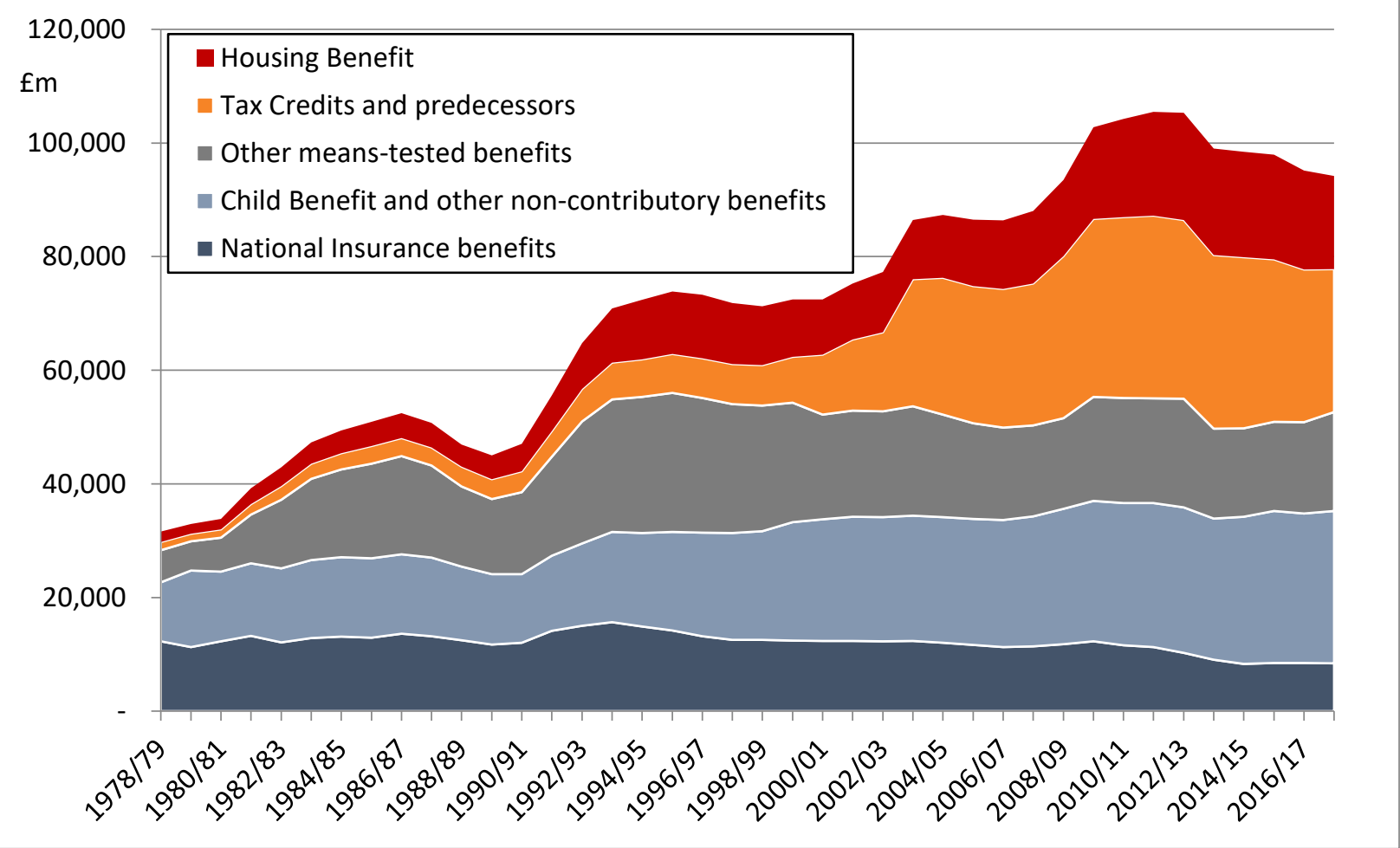


Source: Author's calculations based on Department for Work and Pensions benefit expenditure and caseload tables, Autumn Budget 2017: www.gov.uk/government/publications/benefit-expenditure-and-caseload-tables$\underline{2017}$

This combination of growing inequality in market incomes with increased reliance on transfer payments is hardly unique to the UK, as the OECD (2011) has noted: it can be seen to a varying extent in many developed countries, including both the 'liberal' market economies of the United States and Canada and the 'social democratic' welfare states of Sweden and Finland (Figure 3). The British case is distinctive, however, in three respects. Firstly, the scale of the rise in market inequality during the 1980s was unusually large - from a Gini coefficient of 0.38 in 1975 to 0.47 in 1985 and 0.51 in 1994 - turning one of the most equal market income distributions in the developed world into one of the least equal. Secondly, the development of in-work benefits such as tax credits and Housing Benefit involved not only a quantitative expansion in benefit spending, but also a qualitative shift away from the social insurance model which dominated British welfare policy between the 1940s and the 1980s and towards a system of means-tested social protection. Thirdly, whereas other OECD countries began to roll back their redistributive mechanisms during the long boom of the late 1990s and early 2000s, in Britain the expansion of transfer payments was sustained and deepened. Research by the Institute for Fiscal Studies (IFS) suggests that middle-income households with children derived about 30 per cent of their income from tax credits and other benefits in 2014/15 (Belfield et al., 2016: 49), and the widespread underreporting of benefit income in the Family Resources Survey means that the true figure may be even greater (Corlett et al., 2018). Although UK social policy has always combined elements of 'pre-distribution' and 'redistribution' - direct regulation, collective provision, wage bargaining, taxes, and benefits - the balance between these elements has shifted markedly over the past generation. In an era of widening earnings differentials and declining confidence in state intervention, both Conservative and Labour governments have become 
increasingly reliant on cash transfers to manage the distributional consequences of neoliberalism and globalization.

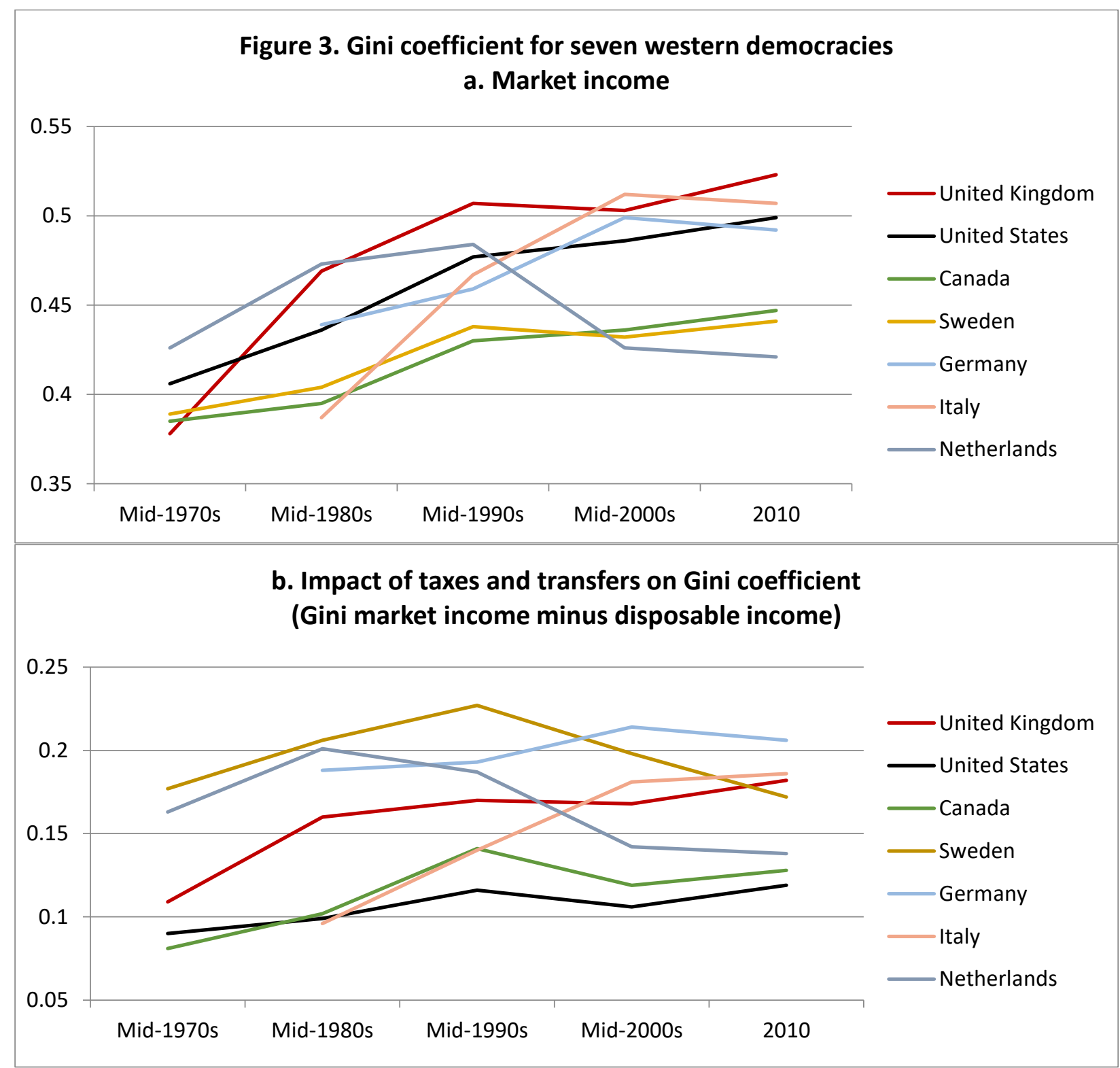

Source: Author's calculations based on OECD data: www.stats.oecd.org

Selected years: UK 1975, 1985, 1994, 2005, 2010; US 1974, 1984, 1995, 2005, 2010; Canada 1976, 1985, 1995 , 2005, 2010; Sweden 1975, 1983, 1995, 2004, 2010; Germany 1985, 1995, 2004, 2010: Italy 1984, 1995, 2004, 2010; Netherlands 1977, 1985, 1995, 2005, 2010.

At first glance, the growth of welfare spending in an age of neoliberalism appears paradoxical. The period since 1979 has been seen by many left-wing commentators as an era of market fundamentalism, characterized by 'dizzying levels of inequality, social decay, [and] 
rampant individualism' - as Andrew Hindmoor (2018: 2) has recently noted. Indeed, in some ways this 'miserabilist' narrative of a welfare state in crisis has been justified by Conservative and New Labour rhetoric. For almost forty years, British governments of all political stripes have declared their suspicion of redistribution and their commitment to clamping down on 'welfare dependency'. Margaret Thatcher's antipathy towards the 'transfer machine' was well known (Sloman, 2016a: 238), and Tony Blair and Gordon Brown worked hard to reposition Labour as a party of 'welfare-to-work' (Levitas, 2005). Despite this rhetoric, however, working-age benefit spending grew inexorably up to the late 2000s. Although rising demand as a result of deindustrialization (Beatty and Fothergill, 2017), unemployment, and other 'new social risks' explains some of this growth, it cannot account for all of it. The scale of cash transfers has been driven upwards both by rising demand on the welfare state - including the unintended consequences of neoliberal policies - and by a series of discretionary policy choices which sit uncomfortably with perceptions of neoliberalism as a small-state doctrine associated with lower taxes and public spending. ${ }^{1}$

How should the paradox of redistribution be explained? One influential interpretation focusses on the functional role which payments such as tax credits and Housing Benefit have come to play in the UK's post-industrial liberal market economy. Drawing on Marxist political economy, the French regulation school, and the 'varieties of capitalism' literature, political economists such as Bob Jessop (2003) and Chris Grover (2016) have argued that the profitability of the UK's service sector relies on a ready supply of cheap and flexible labour. In-work benefits support this accumulation regime by encouraging workers to take low-paid jobs and shifting the cost of maintaining these workers from low-wage employers to other taxpayers. This materialist account is plausible, but the evidence that business lobbying has

\footnotetext{
${ }^{1}$ The growth of disability payments, of course, is also part of this larger story: for a detailed analysis see Hampton (2016).
} 
been the driving force behind policy changes is relatively thin. As Jonathan Hopkin and Kate Alexander Shaw (2016) have pointed out in relation to the growth of the financial sector, the UK's highly centralized policy-making process limits the scope for the kind of 'organized combat' which Jacob Hacker and Paul Pierson (2010) have identified in the United States. Appeals to the immanent logic of liberal market capitalism are even less satisfactory.

This article develops an alternative interpretation of the rise of the UK's 'transfer state' which focusses on the ideological roots of redistribution. Taking its cue from Vivien Schmidt's (2010) 'discursive institutionalist' approach, it argues that the growth of transfer payments is best understood as the product of a particular way of thinking about social policy, which John Kay (1996) has labelled 'Redistributive Market Liberalism’ (RML). Where other approaches to social justice focus on wage bargaining, contributory insurance, and social services, RML suggests that poverty and inequality are best alleviated through income transfers: indeed, that whatever distributional objectives a state might want to achieve - on grounds of equity, efficiency, or social cohesion - are best pursued through the tax and benefit systems. The post-war ascendency of RML can be traced to the intersection of mainstream neoclassical microeconomics with the particular Anglo-American tradition of 'poverty knowledge' identified by Alice O’Connor (2001), which focusses on measuring and alleviating income deficiency. This conjunction reached its apogee in New Labour's child poverty strategy, which sought to reduce the proportion of children living in households with incomes below $60 \%$ of the median - the most explicit distributional target set by any British government.

Recent work by scholars such as Mark Blyth (2003) and Vivien Schmidt (2010) has highlighted the power of ideas to structure policy debate and drive or obstruct innovation, but any ideational account of policy change must also pay close attention to the ways in which ideas are mediated by institutions and interests. As Margaret Weir (1989: 59) pointed out in 
her classic study of the Keynesian revolution, the impact of new ideas depends both on their compatibility with '[t]he institutional arrangements for policy-making' and on their proponents' ability to 'buil[d] coalitions of support for particular policies'. John Myles and Paul Pierson (1997: 445) have explained the rise of tax credit programmes such as the US Earned Income Tax Credit (EITC) in this way: EITC provides a flexible tool for the federal government to target support at low-paid workers, and has facilitated 'the formation of novel, and unexpected, coalitions between those seeking retrenchment... and those concerned about the poor'. As we shall see, a similar process of coalition-building can be traced in the British case, but changing attitudes towards wages and poverty have been at least as important as the changing configuration of interests. As Henry Farrell and John Quiggin (2017) have shown in their recent study of macroeconomic responses to the 2008 financial crisis, new policy problems can bring new sources of expertise to the fore and prompt politicians to form alliances with particular epistemic communities. We need to look not only at the power of business and trade union lobby groups, but also at the contested politics of expertise in postwar Britain and the ways in which exponents of RML have built support for transfer payments inside and outside government.

\section{Transfer payments and the post-war welfare state}

In comparative terms, the UK has always been a relatively liberal market economy, shaped by the global outlook of its political and financial elites and by the early and lasting influence of nineteenth-century political economists. Despite this liberal orientation, the period between the 1940s and the late 1970s witnessed the development of a mixed and managed economy, in which the solidarity forged by the Second World War took concrete expression in public ownership, full employment policies, collective welfare provision, and progressive taxation. 
This period is widely remembered as an era of unprecedented egalitarianism, in which the Gini coefficient for post-tax income fell from 0.43 in 1938 to 0.36 in 1949 and 0.32 in 1976 and the concentration of wealth shrank even faster (Atkinson et al., 2017). For much of this post-war era, however, transfer payments to working-age households were almost nonexistent. Until the early 1970s, social security spending accounted for less than 7\% of GDP, about half of which went on the National Insurance state pension. Adults in paid work were debarred from receiving National Insurance or means-tested National Assistance benefits, and universal Family Allowances - introduced at a rate of five shillings a week for second and subsequent children in 1946 - failed to keep pace with the growth of prices and earnings. In so far as the post-war British state engaged in fiscal redistribution, it did so almost entirely by using progressive taxes on the rich to pay for universal health and education provision and other public services (Daunton, 2002).

The limited role of transfer payments in the post-war welfare state reflected the ideological commitment to paid work shared by much of British society, and above all by the trade unions. Union activity has always been geared towards achieving 'a fair day's wage for a fair day's work', and for much of the twentieth century the British union movement was renowned for its commitment to free collective bargaining. Inter-war debates over family allowances revealed that many trade unionists were deeply suspicious of in-work benefits, fearing that they would subsidize low-wage employment and undermine the dignity of the male breadwinner (Pedersen, 1993). Sir William Beveridge worked closely with the Trades Union Congress in framing his social insurance scheme, and the unions welcomed his decision to focus on providing contributory benefits which would tide workers over 'interruptions of earnings'. The contributory basis of the National Insurance system gave 'respectable' full-time workers a right to benefit, and marked them off from the 'undeserving 
poor' - especially thriftless men and single mothers - who were left to apply for means-tested National Assistance (Levine-Clark, 2015).

The trade unions' suspicion of in-work benefits appears to have been shared by many employers. When the Royal Commission on the Taxation of Profits and Income considered proposals for tax-benefit integration in the early 1950s, the British Employers' Confederation declared that unconditional cash payments would be 'detrimental to productive effort and industrial relations' (Sloman 2016b: 213), and the Federation of British Industries' Taxation Panel agreed that 'it would be a bad principle to bring in social security payments' to make up for the deficiencies of the tax system (Federation of British Industries 1951: 114). Opposition to wage supplements was underpinned by folk-memories of the Speenhamland system, introduced in southern England during the 1790s to relieve wartime distress and keep agricultural workers on the land, but condemned by Thomas Malthus and other classical economists for exacerbating poverty (Block and Somers, 2003). Leading early twentiethcentury economists took a similar view. A.C. Pigou (1932: 728), for instance, believed that means-tested income support would 'greatly weaken the motive of many poor persons to make provision for themselves' and so reduce the national dividend. If a state wanted to eliminate poverty, it was safer to rely on benefits in kind - guaranteeing 'some defined quantity and quality of house accommodation, of medical care, of education, of food... and so on' (Pigou, 1932: 759).

\section{The logic of Redistributive Market Liberalism}

Despite Pigou's strictures, the logic of tackling poverty through cash benefits is both old and simple. Neoclassical economic theory holds that markets are normally the most efficient way of allocating resources between competing uses, and that market wages are set according to 
the marginal productivity of labour. To a market economist it is axiomatic that attempting to raise low incomes through a minimum wage or trade union activity is liable to raise the price of labour above equilibrium level, increasing unemployment and possibly fuelling inflation. Likewise, collective provision of goods and services appears intrinsically inefficient because it is unresponsive to consumer preferences. If poverty is conceptualized in terms of income deficiency - which has been the dominant perspective in British social research since the days of Charles Booth and Seebohm Rowntree - then the simplest way of solving it is to raise incomes which fall below the 'poverty line' (Veit-Wilson, 2006). Kay (1996: 18) has characterized this approach to poverty relief as RML: the belief that ' $[\mathrm{t}]$ he state must have a dominant role in matters of income distribution, but should discharge this responsibility with as little interference as possible in the workings of the free market'.

The neoclassical view of wages as the 'price' of labour was widely shared by British economists before the Second World War (Figart et al., 2002). Even John Maynard Keynes (1930: 119) thought 'the Trade Union solution' of tackling poverty through higher wages risked damaging the UK's competitiveness, and preferred 'the Liberal solution' of raising working-class living standards through social insurance and public services. It was during the 1940s, however, that RML came into its own, as a new generation of liberal economists reassessed Pigou's support for collective provision. In the light of the socialist calculation debate, the proliferation of price controls and subsidies during and after the war came to appear paternalistic and inefficient. In the United States, George Stigler and Milton Friedman developed plans for a Negative Income Tax (NIT), which Friedman later popularized in Capitalism and Freedom (1962). In Britain, liberal and social democratic economists such as James Meade (1948) and Alan Peacock questioned the Attlee government's system of food and housing subsidies and argued that it would be better to focus on cash transfers (Peden, 2017). 'A Liberal social policy designed to maintain minimum standards of comfort may 
require us to intervene positively in the system of public finance in order to redistribute income', Peacock (1957: 117-8) argued, 'but it justifies no other social services other than those which involve transfers of income.'

Although RML derives its coherence and distinctiveness from the neoclassical case for market pricing, it has proved compatible with a variety of ideological traditions. In the hands of neoliberal intellectuals such as Stigler and Friedman, RML appears to be an expression of market fundamentalism, but social democratic, liberal, and conservative thinkers have also developed hybrid forms which vary in four different ways:

- Total versus partial marketization: politicians have generally substituted transfers for regulations and services at the margins, starting with 'low-hanging fruit' (such as consumer subsidies and rent controls) whilst maintaining health and education services which enjoy wider public support.

- Poverty relief versus income equality: social democrats are likely to set more ambitious distributional goals than their conservative counterparts, geared towards the reduction of relative rather than absolute poverty.

- Unconditional versus conditional income support

- Universal versus selective benefits

Many of the most heated debates in contemporary welfare policy can be traced along these four dimensions. For instance, the recent expansion of transfer payments in Britain has been strongly coloured by means-testing and work requirements, which risk exacerbating the precarity of low-paid workers, whereas many left-leaning activists favour a universal and unconditional basic income.

False dawn, c. 1950-1979 
During the 1950s and 1960s, free-market economists and their supporters in the Conservative and Liberal parties sought to establish RML as an organizing principle for British social policy. Between 1951 and 1964, Conservative governments eliminated rationing and food subsidies, encouraged councils to raise rents for better-off tenants, and launched an ambitious (though politically fraught) attempt to deregulate private rented housing. As post-war austerity gave way to consumer affluence, centre-right thinkers such as Peter Goldman (1958) of the Conservative Research Department argued that most citizens would soon be able to meet their own welfare needs through savings and occupational pensions, allowing the welfare state to 'wither away' into a means-tested safety net. Leading Liberal economists such as Peter Wiles (1957) and economic journalists such as Samuel Brittan (1963) took a similar line. Arthur Seldon of the Institute of Economic Affairs called for the abolition of National Insurance and the introduction of markets for health and education in a series of pamphlets on 'choice in welfare', and argued that it would be more efficient to raise the incomes of the poor through NIT (Seldon, 1963).

The growing influence of RML was reinforced by the 'rediscovery of poverty' among pensioners and families with children during the mid-1960s, which revealed the limitations of Beveridge's design. As Bill Jordan (1973: 7) pointed out, '[t]hose who analysed poverty in terms of gaps in the Welfare State' - such as Brian Abel-Smith and Peter Townsend strengthened the case for tackling it through income support, even if they personally favoured a more radical assault on the causes of inequality. Harold Wilson's Labour government recognized that lifting large families above the Supplementary Benefit line through wage increases alone risked exacerbating inflation and unemployment, especially if higher-skilled workers sought to maintain differentials. Many trade union leaders were hostile to a national minimum wage (Oude Nijhuis, 2016), and an interdepartmental working party concluded that this was 'likely to be a less efficient means of relieving poverty than selective social benefits 
related to individual needs' (Department of Employment and Productivity, 1969: 51). The debate thus focussed on the question of whether benefits should be universal or selective (Bale 1999). Although the Child Poverty Action Group and its allies secured an increase in universal Family Allowances in 1968, means-testing continued to grow in other areas. At the Ministry of Housing and Local Government, for instance, Richard Crossman and Anthony Greenwood increased subsidies for council housing, but also encouraged local authorities to target these subsidies on poorer tenants through rent rebates (Malpass, 1990).

The first wave of enthusiasm for RML reached its zenith with the election of Edward Heath's government in 1970, which was explicitly committed to labour- and product-market liberalization and the expansion of 'selectivity'. Heath's flagship Industrial Relations Act 1971 was designed to curb trade union power, whilst the Housing Finance Act 1972 required councils to charge 'fair rents', made rebate schemes mandatory, and introduced rent allowances for private tenants. The government also created a means-tested Family Income Supplement (FIS) - the first explicit form of direct income support for low-paid working families. By the time the Conservatives lost office in 1974, however, this agenda had run into severe practical and political difficulties. Both the Industrial Relations Act and the Housing Finance Act provoked strenuous opposition from the labour movement, and were rapidly repealed after Labour returned to power. FIS was only claimed by about 100,000 families, and was widely criticized for its low take-up and 50\% taper - which, together with income tax and other means-tested benefits, created a so-called 'poverty trap'. The 1974-79 Labour government adopted a more universalist approach to the 'social wage', replacing child tax allowances and Family Allowances with Child Benefit, introducing new disability benefits, and improving National Insurance (especially for pensioners). As Martin Rhodes (2000) has pointed out, however, this came at a political cost, as tensions over the tax increases required to finance social spending contributed to mounting disaffection among skilled workers. 
Why was the expansion of working-age benefits in the 1960s and 1970s so limited? Part of the explanation, no doubt, lies in the power of the unions, which post-war corporatist institutions placed at the heart of economic policy-making (Middlemas, 1986-91). Although male-breadwinner assumptions were beginning to wane by the 1970s, trade union leaders remained suspicious of the concept of the 'social wage' in general and means-tested benefits in particular. Jack Jones (1972) of the Transport and General Workers Union, for instance, argued that using benefits to top-up earnings was 'not a valid alternative to applying consistent, vigorous pressure on employers' to pay a living wage, and would 'make virtual State pensioners of hundreds and thousands of ordinary, healthy men and women'. By contrast, benefits in kind concealed the extent to which the state subsidized working-class living standards, and could not easily be taken into account in wage negotiations.

Significantly, the unions' hostility to wage supplementation was shared by traditionalist Conservatives such as Enoch Powell (1970: 265), who accused Heath of reviving the 'evil' of Speenhamland. If racially-tinged anxieties about the work ethic stood in the way of NIT schemes in the United States, as Brian Steensland (2008) has suggested, cultural categories of identity and social worth also mattered in Britain. One of the obstacles to the adoption of RML was a producerist commitment to the family wage as the foundation of household income, which was rooted in the ethos of the organized working class but extended well beyond it.

Alongside trade union power, the limited impact of RML before 1979 also reflected the contested status of microeconomic expertise among policy-making elites - within what Schmidt (2010: 3) has called the 'coordinative' sphere of policy development. Although the UK economics profession grew rapidly after 1945 and developed close links with Whitehall during the 1960s (Fourcade, 2009), public attention tended to focus on macroeconomic rather than microeconomic issues, with the notable exceptions of tax and industrial relations (John 
et al, 2013: 130-152). The 'Oxford school' of industrial relations founded by Hugh Clegg and Allan Flanders strongly contested the neoclassical theory of the labour market (Ackers, 2016), and Keynes' General Theory lent credence to the notion that government could maintain full employment at any wage rate using fiscal and monetary policy. At the same time, leading sociologists such as Richard Titmuss and Peter Townsend highlighted the symbolic importance of universal benefits and services as an expression of equal social citizenship, and drew attention to the practical difficulties of means-testing. As a result, microeconomics was just one of many forms of policy expertise in a crowded marketplace. It was not difficult for Labour activists to dismiss the case for market pricing as a 'Tory' doctrine, expounded by neoliberal think-tanks in the interests of private profit and social inequality (Jackson, forthcoming).

\section{The ascendancy of market liberalism, c. 1979-2010}

The centrality of wage bargaining and collective provision to the UK's post-war settlement is thrown into sharp relief by comparison with the subsequent ascendancy of market liberalism. Since the late 1970s, British public policy has been strongly shaped by a neoclassical belief in the superior allocative efficiency of market forces, which has driven the deregulation of the labour and housing markets and the introduction of quasi-markets in health and other public services. Though ideological suspicion of 'welfare dependency' has persisted, both Conservative and New Labour governments have expanded transfer payments to mitigate the impact of unemployment and widening pay inequalities. This shift can partly be explained by the collapse of trade union power in the context of deindustrialization (Tomlinson, 2016), but it also reflects the increased cohesion and confidence of mainstream microeconomics. Both the experience of 'stagflation' and Robert Lucas' critique of Keynesian economic 
management served to rehabilitate the neoclassical theory of the labour market and to shift the focus of employment policy from the demand to the supply side. If the prestige of social scientists depends partly on policy influence, as Farrell and Quiggin (2017) suggest, then one effect of the Thatcher government's supply-side approach was to marginalize Keynesians and industrial relations scholars (not to mention sociologists) and to raise the profile and credibility of microeconomics.

Although the decline of trade union membership and collective bargaining practices began during the early 1980 s, the intellectual reaction against the unions' wage politics can be traced back to the previous decade. The 'stagflation' and labour strife of the mid-1970s undermined the social legitimacy of the unions' focus on pay and encouraged economists and social researchers to redefine poverty in terms of total household income. For instance, an influential background paper on The Causes of Poverty for the 1974-79 Royal Commission on the Distribution of Income and Wealth focussed on the 14 million people with household incomes below $140 \%$ of the Supplementary Benefit threshold, and pointed out that only a small minority of these were low earners:

Our conclusion is that, while wages policy can have some equalising effects on wages, these are probably limited... More serious, ... a substantial proportion of the poor are not low-paid. This of itself suggests that the main weight of policy has to be placed on the transfer and tax system (Layard, Piachaud, and Stewart, 1978: 3).

Richard Layard and Steve Nickell's application of the Non-Accelerating Inflation Rate of Unemployment (NAIRU) to Britain reinforced this argument. If wage rigidities raised the NAIRU and exacerbated unemployment, then there was a respectable social democratic case 
for liberalizing the labour market and tackling poverty and inequality through the benefit system (Layard, 1982).

The resurgence of neoclassical labour economics was paralleled by the application of microeconomic analysis to other social policy questions. Alice O'Connor (2001: 213) has shown that federal funding for poverty research in the United States rose from $\$ 3$ million in 1965 to almost \$200 million in 1980, "most designated for the "applied" purposes of measurement, program evaluation, and policy analysis'. Though Britain's 'poverty research industry' was smaller and more eclectic, it followed a similar trajectory of growth and professionalization. Applied work on public economics expanded rapidly under Tony Atkinson's leadership, first at Cambridge and Essex and later at the LSE, where the SuntoryToyota Centre (STICERD) hosted a major programme of econometric research on 'Taxation, Incentives and the Distribution of Income'. Tony Atkinson and Joseph Stiglitz's Lectures in Public Economics (1980), which developed a general equilibrium analysis of public policy and introduced the concept of NIT at an early stage, 'soon established itself as the dominant graduate text in the field' (Sandmo, 2017: 616) and became a primer for many civil servants. By the late 1980s, Martin Ricketts and Edward Shoesmith (1990) found that almost twothirds of UK economists thought the distribution of income in developed countries should be more equal, and that support for fiscal redistribution was much greater than for interventionist policies such as a minimum wage and rent controls. The same logic was visible in the work of the Institute for Fiscal Studies, which used econometric modelling to simulate the distributional effects of budget measures (Dilnot, Kay and Morris, 1984), and in the antipoverty strategy which Dick Taverne devised for the Social Democratic Party (1983).

During the 1970s and 1980s, this network of economists applying microeconomic techniques to the study of poverty and income distribution became an increasingly coherent and influential 'epistemic community' (Haas, 1992). At the same time, the case for tackling 
poverty through transfer payments also received flanking support from other sources. In particular, the publication of John Rawls' A Theory of Justice (1971) sparked a wave of interest in distributive justice among political philosophers. As Stuart White (2014) has noted, Rawls was primarily interested in enabling citizens to interact as social and political equals, and was more concerned about access to 'primary goods' (including civil liberties, opportunities to exercise responsibility, and 'the social bases of self-respect') than the distribution of material resources. However, his 'difference principle' - that inequalities were only justified in so far as they benefited the least advantaged - was frequently conceptualized in income terms, and Rawls (1971: 275) explicitly suggested that the state should use NIT to establish a 'social minimum' outside the labour market. Rawlsian political philosophy thus reinforced the emerging focus on income distribution as the primary barometer of social justice, at the expense of older egalitarian concerns about desert, solidarity, and risk-pooling - as Elizabeth Anderson (1999) has argued. Atkinson and Stiglitz (1980), for instance, drew on Rawls' difference principle to illustrate how normative values might be applied to public policy. Likewise, Julian Le Grand (1982: 132) argued that 'the strategy of promoting equality through public expenditure on the social services ha[d] failed' because spending on health, education, transport, and housing disproportionately benefited the middle classes. Le Grand (1982: 140) concluded that 'a more promising way... of achieving equality of whatever kind would be through equalising incomes'.

Although the shift from 'pre-distribution' to 'redistribution' was clearest in academic and policy-making circles, it can also be traced in public discourse around work and welfare. In particular, the collapse in manufacturing employment and the steady rise in women's labour market participation - from 44.6 per cent in 1971 to 54.2 per cent in 1997 (ONS 2018) - sharply destabilized male-breadwinner assumptions. Indeed, the rhetoric of labour-market 'flexibility' adopted by all parties during the 1980s and 1990s suggested that the patterns of 
part-time, temporary, and service-sector work traditionally associated with women were becoming the new norm (Figart and Mutari, 1999; Fleetwood, 2007). If paid work was no longer a guarantee of economic security, then the state would have to provide some sort of income floor. Geoffrey Evans and James Tilley (2017: 123-126) have highlighted a parallel shift in Labour rhetoric as wage bargaining became less central to the party's outlook between the 1970s and 2000s. Where Labour politicians once appealed to 'the working class' and the unions as the agents and beneficiaries of social justice, New Labour speeches focussed on the need to support 'families' and (to a lesser extent) 'the poor'.

The Conservative governments of 1979-97 were not, of course, enthusiastic about redistribution. Margaret Thatcher viewed poverty in moralistic terms as a symptom of personal failure, and was keen to encourage work and entrepreneurship; Sir Geoffrey Howe and Nigel Lawson reduced the progressivity of the tax structure by cutting income tax rates for high earners, and consistently sought to rein in social security spending. At the same time, however, Tory ministers and officials also recognized the potential value of the benefit system in defusing opposition to market-driven reforms which were likely to impose losses on lower-income households. Housing minister Sir George Young (1991: 940), for instance, pointed out that Housing Benefit would 'underpin market rents' and 'take the strain' of the reduction in council house subsidies. In similar vein, the Central Policy Review Staff (1982: $46,80)$ argued that a more generous system of in-work benefits could help make wage flexibility more acceptable by 'breaking the linkage in the public mind between low pay and family poverty':

An effective mechanism for subsidising the earnings of low income families could encourage the acceptance of low paid jobs, reduce upward wage pressures 
for family men, increase incentives to seek work and facilitate the growth of part-time employment.

This logic informed the rationalization of means-tested benefits in Norman Fowler's 1984-5 social security reviews and the replacement of FIS with the more generous Family Credit. Although Thatcher (1984) was initially sceptical about expanding family income support, advisers such as John Redwood pointed out that it was a useful way of burnishing the government's social credentials (Moore, 2015: 429). Employers' representatives also welcomed the move, since it 'allow[ed] legitimate business to compete with those in the black economy who traditionally pay low wages' (Department of Social Security Employers' Panel, 1995). At the same time, the Department of Health and Social Security's institutional commitment to social insurance was weakened by the promotion of former National Assistance Board officials such as Sir Kenneth Stowe (permanent secretary, 1981-87) and Dame Ann Bowtell (permanent secretary, 1995-99), who were more comfortable with the expansion of means-testing than officials from the National Insurance divisions. Rising housing costs - exacerbated by financial liberalization and council house sales - and the growth of single-parent households added to the burden on this safety net. By 1997, more than 2.8 million non-pensioner households were claiming Housing Benefit and more than 700,000 were receiving Family Credit.

If the expansion of transfer payments under the Conservatives was reluctant and defensive, New Labour's embrace of RML was much more proactive. As Jane Jenson (2012: 24) has pointed out, many finance ministries around the world came to see targeted transfer payments as the most efficient way of tackling poverty during the 1980s and 1990s, and 'puzzled through the design of tax-based and income-contingent policy instruments' with encouragement from the OECD and World Bank. Under Gordon Brown, the UK Treasury 
asserted its position as the dominant social policy actor in Whitehall and turned Tony Blair's 1999 pledge to abolish child poverty by 2020 into an explicit set of relative poverty targets (Deakin and Parry, 2000). Brown replaced Family Credit with a system of tax credits, paid by the Inland Revenue as an addition to the worker's pay packet, and expanded the system in successive budgets so that by 2010 it was distributing almost $£ 30$ billion. Although Brown publicly presented tax credits as a welfare-to-work measure, he privately recognized that they formed 'a top-up for low wages' (Ashdown, 2000: 486) and provided a means of redistribution by stealth. Decomposition analysis by Richard Dickens (2011) suggests that the reduction in child poverty between 1997/98 and 2008/09 was driven almost entirely by increases in tax credits and other benefits, with changes in wages and work patterns making a negligible contribution. In particular, the National Minimum Wage - which had become a flagship Labour commitment under Neil Kinnock's leadership in the late 1980s and early 1990s - was introduced in 1999 at just $£ 3.60$ an hour, less than $50 \%$ of median earnings (Blackburn, 2007: 192-200). Despite pressure from the unions, Blair and Brown kept its initial rate down in order to limit the impact on business costs and job creation. In a period of economic growth and rising tax revenues, cash transfers offered a more attractive way of raising the living standards of low-paid workers.

John Kay (2010) has argued that RML was 'the dominant economic philosophy in the British Treasury' during the 1990s and 2000s. As a leaked paper admitted in the mid-1990s, 'Treasury officials have a high level of commitment to the efficiency of the market mechanism, to neo-classical welfare economics and to the utilitarian ethics on which they are based' (quoted in Kaletsky, 1996). In truth, however, the logic of RML was only ever implemented in a hybrid and attenuated form. Whereas earlier enthusiasts - such as Friedman and Meade - had favoured a guaranteed income for everyone, the Thatcher, Major, and Blair governments tightened work requirements for benefit claimants and focussed on raising the 
incomes of low-paid workers. Jobseekers' Allowance, tax credit and Universal Credit have linked transfer payments with 'activation for all' (Griggs et al., 2014) and reproduced the age-old cultural distinction between the 'deserving' and 'undeserving' poor. The influence of RML within the Treasury was also limited by Gordon Brown's interest in endogenous growth theory, which provided a basis for reviving and recasting Labour's tradition of 'supply-side socialism' (Thompson, 2006). As Kay (2010) notes, the Treasury's target-driven approach to the public services suggested that Brown was never wholly convinced by the case for marketization.

\section{Conclusion: From redistribution to 'pre-distribution'?}

The growth of transfer payments in Britain since the 1970s has been driven by a complex nexus of factors, including long-term social and economic trends (such as deindustrialization) and the unintended consequences of policy failure (for instance, in housing policy) as well as overt policy choices. Social policy specialists have understandably focussed on the qualitative shift away from a contributory social insurance model towards a means-tested safety-net for the working poor, and the ways in which behaviouralist ideas about a socially excluded 'underclass' have justified increasingly coercive forms of conditionality (Levitas, 2005; Grover, 2016). The analysis developed in this article suggests, however, that the latetwentieth-century restructuring of the British welfare state also involved a shift from a social politics based on wage bargaining and collective provision to a social politics of cash transfers. The concept of Redistributive Market Liberalism provides a useful starting-point for thinking about the nature and limits of this process.

By the last quarter of the twentieth century, RML had assumed the status of "common sense' within the economics profession, and policy-makers' perceptions of the labour market 
and the welfare state were increasingly shaped by microeconomic analysis. The experience of stagflation and mass unemployment during the 1970s and 1980s encouraged economists and politicians to problematize collective bargaining and reconceptualize income distribution as a matter of tax and benefit policy. Conservatives turned to the neoclassical theory of the labour market to justify deregulation and reassign responsibility for unemployment from the state to the unions, whilst SDP and New Labour politicians drew on work by applied economists such as Atkinson and Layard to show that their distributional objectives could be achieved through cash transfers. Under the Thatcher and Major governments, ministers reluctantly accepted the growth of working-age benefits as a way of defusing opposition to free-market reforms; under New Labour, the Treasury embarked on a more ambitious attempt to redistribute the proceeds of growth, offset the rising inequality of market income, and eliminate child poverty. Although monetary policy became the primary tool of macroeconomic management after 1979, fiscal transfers remained central to economic and social policy.

Hopkin and Alexander Shaw (2016: 364) have argued that the 'Big Bang' in the City of London and the financial liberalization that followed was primarily a state-led process, 'implemented by an ideologically motivated elite that was ahead of the domestic business lobby in its commitment to free markets'. The expansion of working-age transfer payments can be seen in a similar light: Housing Benefit and tax credits, in particular, were devised by politicians and policy experts in Whitehall, and rarely featured on the hustings. By the 1990s, the use of means-tested transfers to tackle poverty appeared to offer a pragmatic and costeffective way of providing income security within a liberal welfare state, and attracted relatively little resistance on either side of the Atlantic (Myles and Pierson, 1997). Although key interest groups acquiesced in New Labour's anti-poverty strategy, however, none of them were wholly enthusiastic about the form it took. The Confederation of British Industry 
(1998), for instance, 'supported the use of in-work benefits... as an alternative to a minimum wage set too high', but bridled at the scale of redistribution which Brown pursued and the administrative burden of tax credits (Confederation of British Industry, 2000). Conversely, anti-poverty campaigners such as the Child Poverty Action Group welcomed the child poverty targets but criticized the government's heavy reliance on means-testing (Thane and Davidson, 2016). Likewise, Rafael Ziegler and Bill Jordan (2001) found that union officials were 'rather passively accepting... of the move towards tax credits' during the late 1990s but retained 'an unmodified ideal of decent wages and national insurance benefits as the best approach to income maintenance'. By the mid-2000s, the unions were increasingly throwing their energies into living wage campaigns, challenging the government's focus on household poverty and its commitment to a flexible labour market (Wills and Linneker, 2014).

Evidence from the British Social Attitudes Survey suggests that public support for RML is also limited. Although more than three-quarters of Britons have consistently said that the gap between high and low incomes is 'too large', only about two-fifths believe that the government should solve this problem by redistributing income (Figure 4). The principle of topping-up the wages of low earners with children enjoys relatively wide support, but there is little enthusiasm for transfer payments to working couples without children (Figure 5). When Britons were asked how the government should tackle inequality in 2009, making the tax system more progressive, raising the minimum wage, and improving education and job opportunities were much more popular options than improving benefits (Figure 6). 


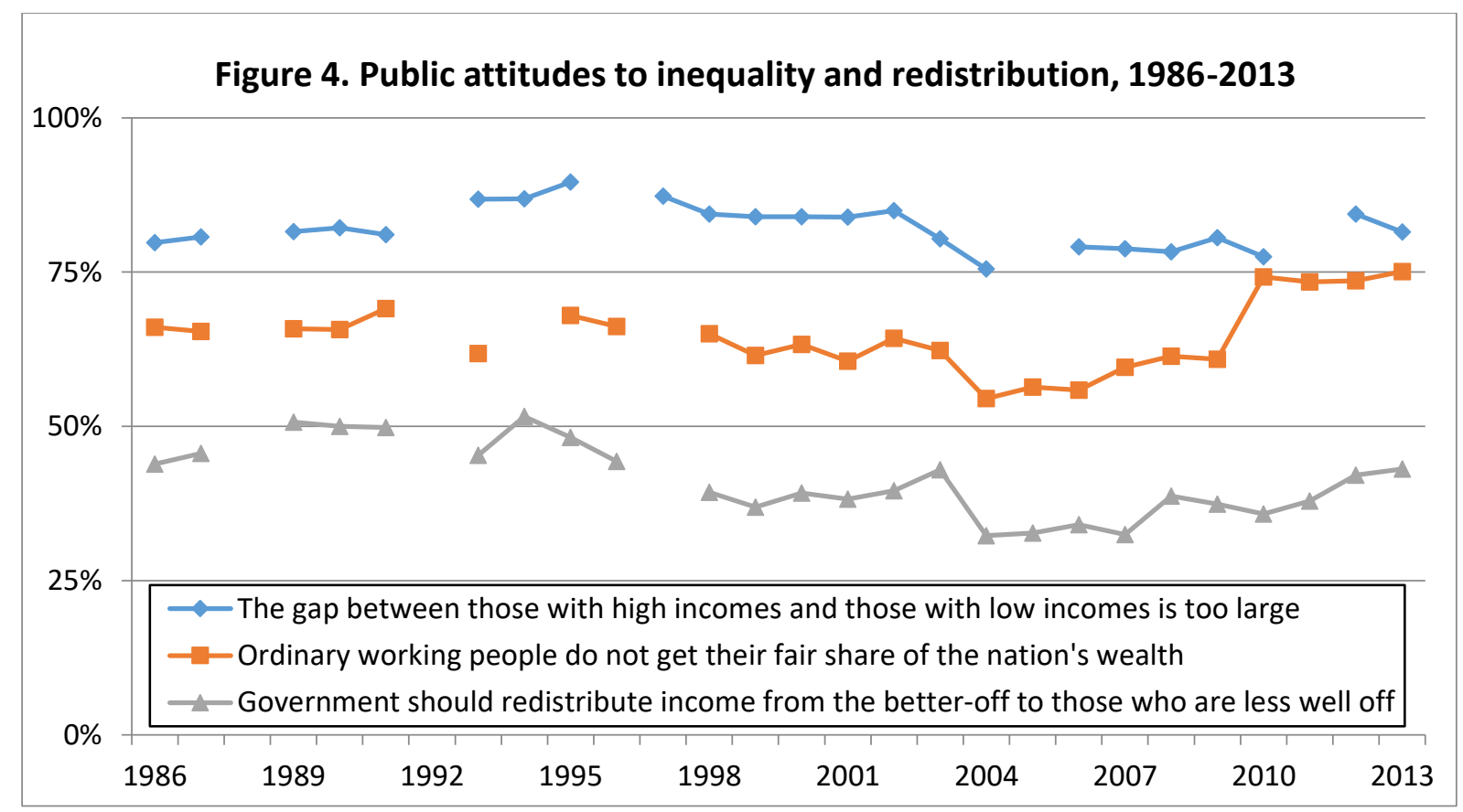

Source: British Social Attitudes Survey, 1986-2013: proportion of respondents agreeing with each statement

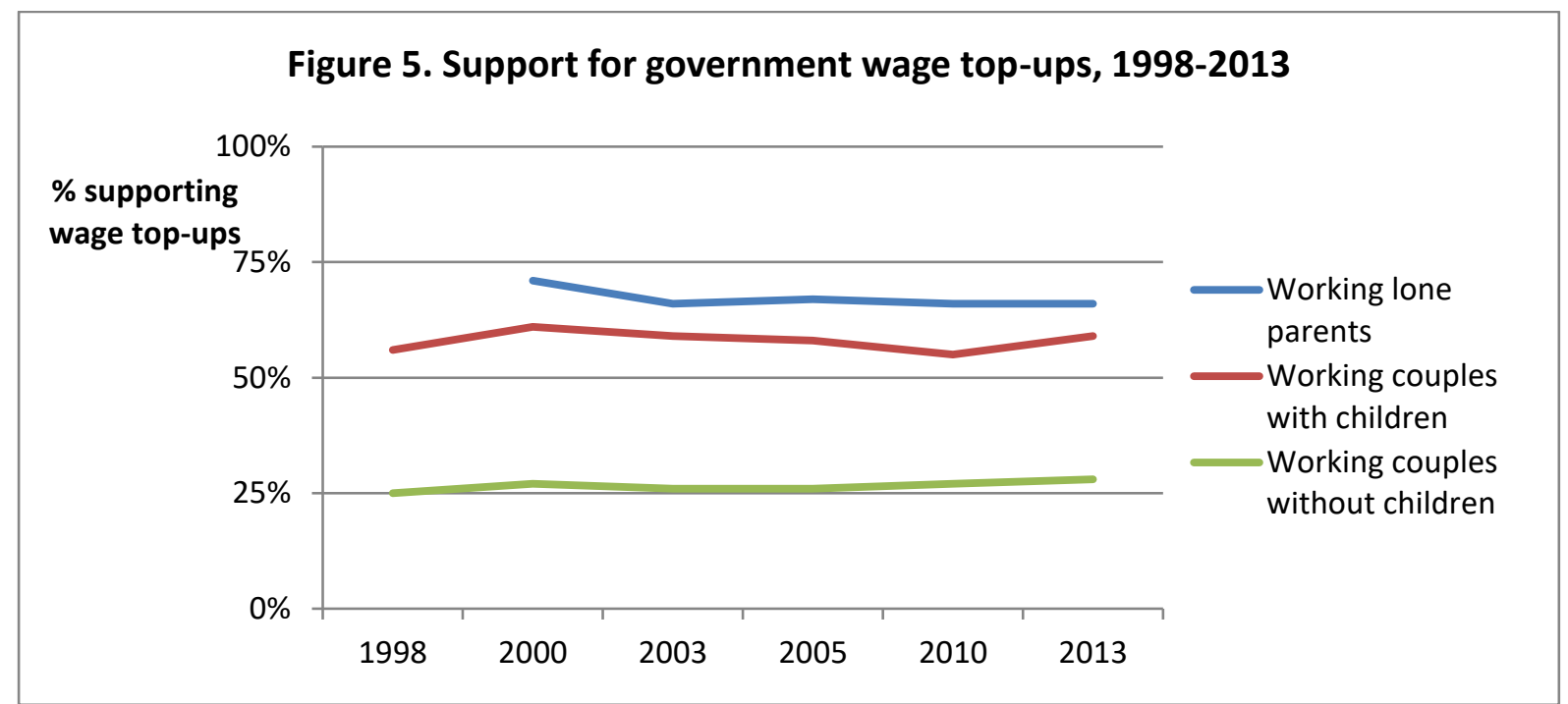

Source: British Social Attitudes Survey, 1998-2013: 'Some [working lone parents/couples with children/couples without children] find it hard to make ends meet on low wages. In these circumstances, do you think the government should top up their wages, or, is it up to the [parent/couple] to look after themselves [and their children] as best they can?' 


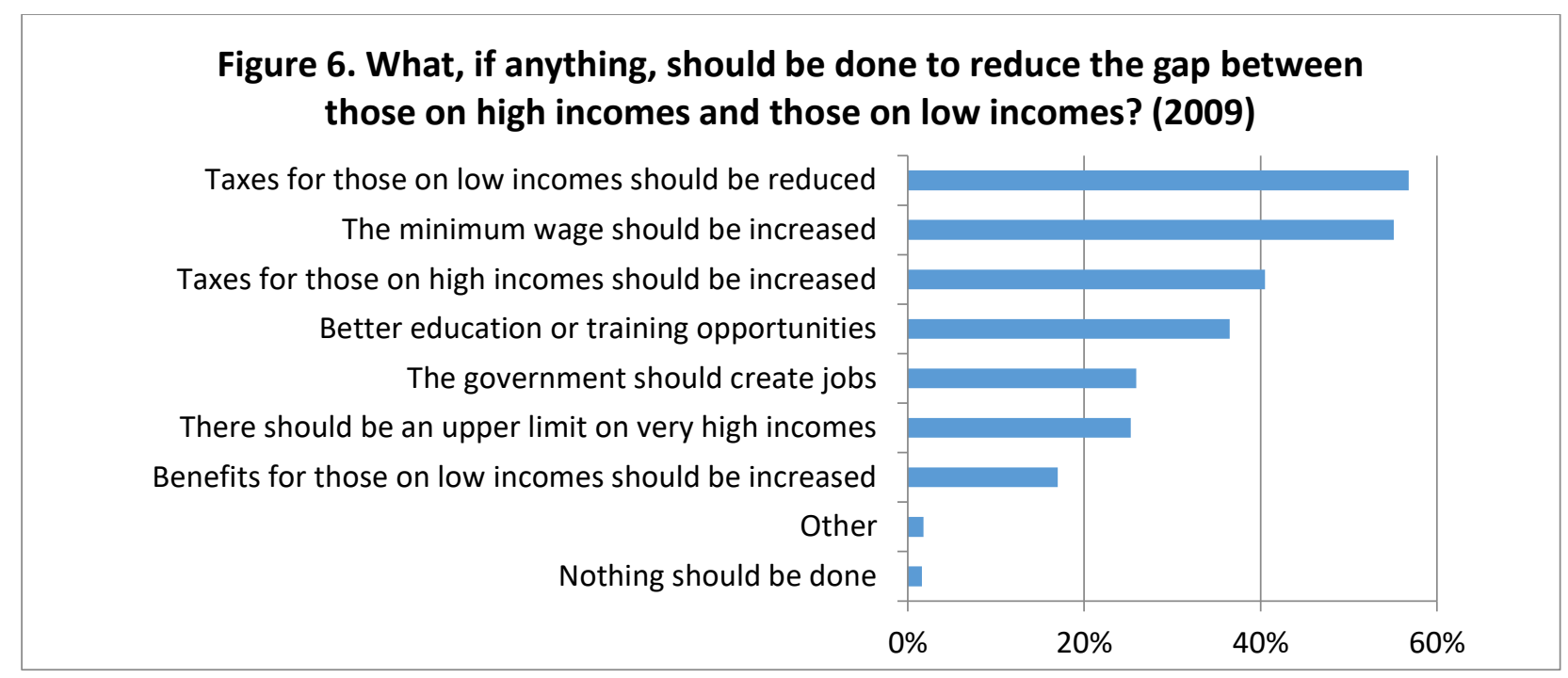

Source: British Social Attitudes Survey, 2009: proportion of respondents mentioning each option

Looking at contemporary welfare politics in this light makes it easier to understand the turn away from redistribution which has taken place since 2010. In an era of slow growth and weak tax revenues, public attitudes towards 'welfare' have hardened and the Treasury has turned to benefit cuts as a means of reducing the deficit. Not only was George Osborne's rhetorical assault on 'shirkers' and 'scroungers' shrewd politics, but the headline distributional measures which he adopted from his rivals - the $£ 10,000$ tax threshold proposed by the Liberal Democrats and the higher minimum wage championed by Ed Miliband - have both served to reduce the need for in-work benefits. Daniel Clegg (2015: 497) has suggested that these policies might form the basis of a new 'Make Work Pay consensus' which reflects a deeply-rooted preference for earned over unearned income. As Will Davies (2016) has pointed out, New Labour offered those who had been displaced by economic change "“redistribution" but no "recognition"”. The male-breadwinner culture of Britain's post-industrial heartlands has probably gone for good, but higher take-home pay can at least give workers 'the dignity of being self-sufficient'.

A decade on from the financial crisis, the technocratic politics of the 1990s and 2000s has come to appear distinctly passé. Both the UK's vote to leave the European Union and Jeremy Corbyn's unexpectedly strong performance in the 2017 general election have shown 
the electoral appeal of bold policies which promise to tackle the root causes of social malaise, not just address the symptoms. The prospects for achieving social justice through 'predistribution', however, remain uncertain. Rebalancing housing spending 'from benefits to bricks' is likely to be a costly and protracted process, whilst further increases in the minimum wage run the risk of damaging low-skilled employment and exacerbating the disruptive impact of automation. In these circumstances, it is far from clear that the new wave of interventionist policies will ever go far enough to make a wholesale assault on working-age benefits politically possible. For all its faults, the redistributive apparatus of the 'transfer state' is thus likely to remain at the heart of British public policy.

\section{Acknowledgements}

An early version of this article was presented at the 2017 Political Studies Association conference in Glasgow and I am grateful to Prof Hugh Pemberton, Dr Andrew Crines, and other participants for their constructive feedback. I would also like to thank Prof Jason Sharman, Prof Andrew Hindmoor, and the anonymous reviewers for their helpful comments. 


\section{References}

Ackers P (2016) Symposium: The Oxford school of industrial relations: Fifty years after the 1965-1968 Donovan Commission. Historical Studies in Industrial Relations, 37: 201-207. Anderson ES (1999) What is the point of equality? Ethics, 109 (2): 287-337. Ashdown P (2000) The Ashdown Diaries. Volume 1: 1988-1997. London: Allen Lane. Atkinson AB, Hasell J, Morelli S and Roser M (2017) The Chartbook of Economic Inequality. Available at: https://www.chartbookofeconomicinequality.com/ (accessed 19 Jan. 2018).

Bale T (1999) Sacred Cows and Common Sense: The Symbolic Statecraft and Political Culture of the British Labour Party. Aldershot: Ashgate.

Beatty C and Fothergill S (2017) The impact on welfare and public finances of job loss in industrial Britain. Regional Studies, Regional Science, 4 (1): 161-180.

Belfield C, Cribb J, Hood A and Joyce R (2016) Living Standards, Poverty and Inequality in the UK: 2016. London: Institute for Fiscal Studies.

Blackburn, S (2007) A Fair Day's Wage for a Fair Day's Work? Sweated Labour and the Origins of Minimum Wage Legislation in Britain. Aldershot: Ashgate.

Blair, T (1994) Speech to Labour Party conference, 4 Oct. Available at:

http://www.britishpoliticalspeech.org/speech-archive.htm?speech=200 (accessed 4 July 2017).

Block F and Somers M (2003) In the shadow of Speenhamland: Social policy and the Old Poor Law. Politics \& Society, 31 (2): 283-323.

Blundell R (2006) Earned Income Tax Credit policies: Impact and optimality. The Adam Smith lecture, 2005. Labour Economics, 13 (4): 423-443. 
Blyth M (2003) Structures do not come with an instruction sheet: Interests, ideas, and progress in political science. Perspectives on Politics, 1 (4): 695-706.

Brittan S (1963) How to reform the welfare state. The Observer, 10 Oct.

Central Policy Review Staff (1982) 'Report on Unemployment', Sept. In The National Archives: Public Record Office, CAB 184/610.

Cherrier B (2017) Remembering Tony Atkinson as the architect of modern public economics. In: The Undercover Historian blog, 2 Jan. Available at:

https://beatricecherrier.wordpress.com/2017/01/02/remembering-tony-atkinson-as-thearchitect-of-modern-public-economics/ (accessed 24 Jan. 2018).

Clegg D (2015) The demise of tax credits. Political Quarterly, 86 (4): 493-499.

Confederation of British Industry (1998) The Working Family Tax Credit. CBI evidence to the House of Commons Social Security Committee Tax and Benefits Enquiry. Modern Records Centre, University of Warwick, MSS.200/C/2008/Box 84.

Confederation of British Industry (2000) Brief for Digby Jones on Working Families Tax Credit, 3 May. Modern Records Centre, University of Warwick, MSS.200/C/2008/Box 70. Corlett A, Clarke S, D’Arcy C and Wood J (2018) The Living Standards Audit 2018. London: Resolution Foundation.

Daunton M (2002) Just Taxes: The Politics of Taxation in Britain, 1914-1979. Cambridge: Cambridge University Press.

Davies W (2016) Thoughts on the sociology of Brexit. In: Political Economy Research Centre blog, 24 June. Available at: http://www.perc.org.uk/project_posts/thoughts-on-thesociology-of-brexit/ (accessed 4 July 2017).

Deakin N and Parry R (2000) The Treasury and Social Policy: The Contest for Control of Welfare Strategy. Basingstoke: Macmillan. 
Department of Social Security Employers' Panel (1995) Minutes of the Meeting of the DSS Employers' Panel, 22 June. Modern Records Centre, University of Warwick, MSS.200/C/2008/Box 85 DSS/NIC/Social Security/Employers' Group. Department of Employment and Productivity (1969) A National Minimum Wage: Report of an Inter-Departmental Working Party. London: Her Majesty’s Stationery Office.

Dickens R (2011) Child Poverty in Britain: Past lessons and future prospects. National Institute Economic Review, 218: R7-R19.

Dilnot AW, Kay JA and Morris CN (1984) The Reform of Social Security. Oxford: Oxford University Press.

Evans G and Tilley J (2017) The New Politics of Class: The Political Exclusion of the British Working Class. Oxford: Oxford University Press.

Farrell H and Quiggin J (2017) Consensus, dissensus, and economic ideas: Economic crisis and the rise and fall of Keynesianism. International Studies Quarterly, 61 (2): 269-283. Federation of British Industries (1951) Minutes of Taxation Panel meeting, 7 Dec. Modern Records Centre, University of Warwick, MSS.200/F/1/1/135/112-5.

Figart DM and Mutari E (1999) Global feminization and flexible labour markets: Gendered discourse in the opposition to pay equity reform. In Gregory J, Sales R and Hegewisch A (eds) Women, Work and Inequality. London: Palgrave Macmillan.

Figart DM, Mutari E and Power M (2002) Living Wages, Equal Wages: Gender and Labor Market Policies in the United States. London: Routledge, pp. 44-57.

Fleetwood S (2007) Why work-life balance now? The International Journal of Human Resource Management, 18 (3): 387-400.

Fourcade M (2009) Economists and Societies: Discipline and Profession in the United States, Britain, and France, 1890s to 1990s. Princeton, NJ: Princeton University Press. Friedman M (1962) Capitalism and Freedom. Chicago, IL: University of Chicago Press. 
Goldman P (1958) Preface. In Conservative Political Centre, The Future of the Welfare State. London: Conservative Political Centre.

Griggs J, Hammond A and Walker R (2014) Activation for all: Welfare reform in the United Kingdom, 1995-2009. In Lodemel I and Moreira A (eds) Activation or Workfare?

Governance and the Neo-Liberal Convergence. Oxford: Oxford University Press, pp. 73-100. Grover C (2016) Social Security and Wage Poverty: Historical and Policy Aspects of Supplementing Wages in Britain and Beyond. Basingstoke: Palgrave Macmillan. Haas PM (1992) Introduction: Epistemic communities and international policy coordination. International Organization, 46 (1): 1-35.

Hacker J (2011) The institutional foundations of middle-class democracy. In Priorities for a New Political Economy: Memo to the Left. London: Policy Network, pp. 33-37.

Hacker J and Pierson P (2010) Winner-take-all politics: Public policy, political organization, and the precipitous rise of top incomes in the United States. Politics \& Society, 38 (2): 152204.

Hampton J (2016) Disability and the Welfare State in Britain: Changes in Perception and Policy 1948-79. London: Policy Press.

Hindmoor A (2018) What's Left Now. Oxford: Oxford University Press. Hopkin J and Alexander Shaw K (2016) Organized combat or structural advantage? The politics of inequality and the winner-take-all economy in the United Kingdom. Politics \& Society, 44 (3): 345-371.

Jackson B (forthcoming) Richard Titmuss versus the IEA: The transition from idealism to neo-liberalism in British social policy. In Goldman L and Jones S (eds) Welfare and Social Policy in British Historical Perspective, 1850-2010.

Jessop B (2003) From Thatcherism to New Labour: Neo-liberalism, workfarism, and labour market regulation. In Overbeek H (ed) The Political Economy of European Employment: 
European Integration and the Transnationalization of the (Un)employment Question.

London: Routledge, pp. 137-153.

John P, Bertelli A, Jennings W and Bevan S (2013) Policy Agendas in British Politics.

Basingstoke: Palgrave Macmillan.

Jones J (1972) Wages and social security. New Statesman, 7 January, 7.

Jordan B (1973) Paupers: The Making of the New Claiming Class. London: Routledge and Kegan Paul.

Kaletsky A (1996) Why the Treasury must now be brought to heel. The Times, 18 July, 27.

Kay J (1996) Staking a moral claim. New Statesman, 11 October, 18-20.

Kay, J (2010) The left is still searching for a practical philosophy. Financial Times, 5 May.

Keynes JM (1930) The question of high wages. Political Quarterly, 1 (1): 110-124.

Labour Party (2017) For the Many, Not the Few: The Labour Party Manifesto 2017. London:

Labour Party.

Layard R (1982) More Jobs, Less Inflation: The Case for a Counter-Inflation Tax.

London: Grant McIntyre.

Layard R, Piachaud D and Stewart M (1978) The Causes of Poverty. London: Her

Majesty's Stationery Office.

Le Grand J (1982) The Strategy of Equality: Redistribution and the Social Services. London:

George Allen and Unwin.

Levine-Clark M (2015) Unemployment, Welfare, and Masculine Citizenship: 'So Much

Honest Poverty’ in Britain, 1870-1920. Basingstoke: Palgrave Macmillan.

Levitas R (2005) The Inclusive Society? Social Exclusion and New Labour. Second edition,

Basingstoke: Palgrave Macmillan. 
McDonnell J (2016) Speech to Labour Party conference, 16 Sept. Available at:

https://www.policyforum.labour.org.uk/news/john-mcdonnell-s-speech-to-annual-

conference-2016 (accessed 16 Aug. 2018).

Malpass P (1990) Reshaping Housing Policy: Subsidies, Rents and Residualisation. London:

Routledge.

Meade JE (1948) Planning and the Price Mechanism: The Liberal-Socialist Solution.

London: George Allen \& Unwin.

Middlemas K (1986-91) Power, Competition and the State. 3 vols., Basingstoke: Macmillan. Moore C (2015) Margaret Thatcher: The Authorized Biography. Volume 2: Everything She Wants. London: Allen Lane.

Myles J and Pierson P (1997) Friedman's revenge: The reform of "liberal" welfare states in Canada and the United States. Politics \& Society, 25 (4): 443-472.

O’Connor A (2001) Poverty Knowledge: Social Science, Social Policy, and the Poor in Twentieth-Century U.S. History. Princeton: Princeton University Press.

OECD (2011) Divided We Stand: Why Inequality Keeps Rising. Paris: OECD Publications. ONS (2018) Labour Market Statistics time series MGWI. Available at: https://www.ons.gov.uk/employmentandlabourmarket/peopleinwork/employmentandemploye etypes/datasets/labourmarketstatistics (accessed 6 August 2018).

Osborne G (2015) Summer Budget speech, 8 July. Available at: www.gov.uk/government/speeches/chancellor-george-osbornes-summer-budget-2015-speech (accessed 4 July 2017).

Oude Nijhuis D (2016) Low pay, wage relativities, and Labour's first attempt to introduce a statutory national minimum wage in the United Kingdom. Journal of Policy History, 28 (1): 81-104. 
Peacock AT (1957) Welfare in a Liberal state. In Watson G (ed) The Unservile State: Essays in Liberty and Welfare. London: George Allen \& Unwin, pp. 113-130.

Peden G (2017) Neoliberal economists and the British welfare state, 1942-1975. Journal of the History of Economic Thought, 39 (4): 413-427.

Pedersen S (1993) Family, Dependence, and the Origins of the Welfare State: Britain and France, 1914-1945. Cambridge: Cambridge University Press.

Powell JE (1970) Speech in the House of Commons, 10 November. HC Deb, 806: 260-265. Rawls J (1971) A Theory of Justice. Cambridge, MA: Belknap Press.

Rhodes M (2000) Desperately seeking a solution: Social democracy, Thatcherism and the "Third Way" in British welfare. In Ferrera M and Rhodes M (eds) Recasting European Welfare States. London: Frank Cass, pp. 161-186.

Ricketts M and Shoesmith E (1990) British Economic Opinion: A Survey of a Thousand Economists. London: Institute of Economic Affairs.

Sandmo A (2017) Tony Atkinson 1944-2017: A lifetime commitment to the study of inequality. European Journal of the History of Economic Thought, 24 (3): 612-623. Schmidt V (2010) Taking ideas and discourse seriously: Explaining change through discursive institutionalism as the fourth "new institutionalism". European Political Science Review, 2 (1): 1-25.

Seldon A (1963) Choice in Welfare. London: Institute of Economic Affairs.

Sloman P (2016a) “The pragmatist's solution to poverty”: The Heath government's Tax Credit Scheme and the politics of poverty in the 1970s. Twentieth Century British History, 27 (2): $220-241$.

Sloman P (2016b) Beveridge's rival: Juliet Rhys-Williams and the campaign for basic income, 1942-1955. Contemporary British History, 30 (2): 203-223. Social Democratic Party (1983) Attacking Poverty. London: Social Democratic Party. 
Steensland B (2008) The Failed Welfare Revolution: America's Struggle Over Guaranteed Income Policy. Princeton: Princeton University Press.

Thane P and Davidson R (2016) The Child Poverty Action Group in the 1990s and 2000s:

Witness Seminar. London: Institute of Contemporary British History.

Thatcher M (1984) Marginal annotations on letter from Willetts D to Prime Minister, 'Benefits for Children and Young People', 28 Dec. In The National Archives: Public Record Office, PREM 19/1638.

Thompson N (2006) Political Economy and the Labour Party: The Economics of Democratic Socialism, 1884-2005. Second edition, London: Routledge.

Tomlinson J (2016) De-industrialization not decline: A new meta-narrative for post-war British history. Twentieth Century British History, 27 (1): 76-99.

Veit-Wilson J (2006) Poverty. In Fitzpatrick T et al. (eds) International Encyclopaedia of Social Policy. Abingdon: Routledge, vol. I, pp. 1036-1042.

Weir M (1989) Ideas and politics: The acceptance of Keynesianism in Britain and the United States. In Hall PA (ed) The Political Power of Economic Ideas: Keynesianism Across Nations. Princeton, NJ: Princeton University Press, pp. 53-86.

White S (2014) Democratic equality as a work-in-progress. In Mandle J and Reddy DA (eds) A Companion to Rawls. Chichester: Wiley-Blackwell, pp. 185-99.

Wiles P (1957) Property and equality. In Watson G (ed) The Unservile State: Essays in Liberty and Welfare. London: George Allen \& Unwin, pp. 88-109.

Wills J and Linneker B (2014) In-work poverty and the living wage in the United Kingdom: A Geographical Perspective. Transactions of the Institute of British Geographers, 39 (2): 182-194.

Young Sir G (1991) Oral answer in the House of Commons, 30 January. HC Deb, 184: 940. 
Ziegler R and Jordan B (2001) The trade unions, tax-benefit reform and basic income: Stumbling towards a policy? Citizen's Income Trust Newsletter, 3. 